\title{
1.3 Особливості формування лісового біоценозу в культурах сосни звичайної на прикладі ДП «Чигиринське лісове господарство»
}

Сучасні природні лісові біоценози пройшли довгий шлях формування й розвитку. Ліс $є$ представником найдревніших типів рослинності, укладеним 3 вищих рослин, предки яких з'явились на землі близько 300-400 млн. років тому. Всі еволюційні процеси органічного світу невіддільно, в єдиному конгломераті, впливали на об’єкти живої й неживої природи, при цьому зазнаючи певних змін, відбувалось становлення кожної складової живої оболонки нашої землі біосфери. Звичайно, царству рослин тут відведена неабияка роль, оскільки, саме автотрофи зуміли синтезувати органічні речовини з неорганічних, при цьому виділяючи кисень, що в подальшому дало поштовх для формування інших форм життя і сучасного біорізноманіття.

Ліс - складне утворення інтегрованих в єдину складну систему великої кількості різноманітних рослин та інших живих істот, які сильно різняться за своїми розмірами, будовою, способом розмноження, типом харчування. Дерева як весь флористичний склад в лісі в результаті взаємовідносин між собою, здійснюють взаємний вплив. Звідси, ліс насить назву рослинного угрупування, або фітоценоз.

Кожному типу лісу властивий певний набір лісових рослин, який відповідає тим чи іншим природним умовам. Звідси, у складі лісу можна знайти тих представників фауни, які пристосовані, крім сумісного існування, до певних грунтово-кліматичних факторів. Особливо яскраво це можна спостерігати на невеликих рівнинних просторах, зокрема на території лісництв.

В межах України надзвичайно поширеними $є$ хвойні ліси, які займають другу позицію після листяних лісів. Особливої уваги на території України заслуговують соснові ліси - угруповання звичайнососнових, кримськососнових, кохососнових, піцундськососнових та європейськокедрових лісів. Найбільш поширеними є угруповання звичайнососнових лісів, які відзначаються низкою особливостей: основним лісотвірним видом $\epsilon$ сосна звичайна; iii лісові 
угруповання характеризуються високою пластичністю та едифікаторною адаптивністю; досить широка популяційна територія едифікатора стали поштовхом до його кліматичної, рельєфної й грунтової неоднорідності; спостерігається значна синтаксономічна різноманітність. На території України сосні відводиться почесне місце. Зокрема, фактично існує 17 видів, 3 яких в культурі 11, найбільш розповсюджена сосна звичайна (Pinus sylvestris L.). Звичайнососнові ліси (Pineta sylvestris) різноманітні за флористичним складом, таксаційними даними та ценотичними особливостями [50, с. 42].

Формування соснових борів на території Черкаської області зумовлено іiі клімато-географічними умовами: за цими ознаками вона поділяється на дві великі частини - лівобережну та правобережну. Остання відноситься до Придніпровської височин, де можна спостерігати активні ерозійні процеси. Наявність глибоких ярів пояснюється різницею абсолютних відміток рельєфу, що набуває гірського характеру. Такі явища сприяли утворенню Канівських гір та Мошногірського кряжу. На Лівобережній частині наявна Придніпровська низовина, де місцями розміщена горбиста, заболочена рівнина.

На формування літосферних відкладів сучасної території області в процесі геологічних циклів впливали магматичні породи докембрійського періоду Українського кристалічного щита, також, на згадані процеси здійснювали достатній ефект осадові гірські породи палеозойської, мезозойської ери (глини, пісковики, мергелі). Продукти докембрійського періоду з’являються на верхніх відкладах Правобережної частини по берегах річок. Як свідчать наукові дослідження, у мезозойску і кайнозойску еру тут знаходилось море. У тріасовий період утворились різнозернисті піскові утворення з включеннями глиняного походження, а також залишків вапняків. На території Канівських гір часто зустрічаються відкладення піскових структур, глини темного сірого забарвлення, алевроліти i, звичайно, можна спостерігати нашарування пісковиків та вапняних порід юрського періоду, що відшаровуються на підвищеннях ярів і балок. Утворення періоду палеогену і неогену зустрічаються локально на Правобережжі. На кристалічних породах Українського щита 
знаходяться піщано-глинисті породи і вапняки. Льодовики, що відступили 12 тисяч років по тому, залишили піщано-глинисті опади, суглинки, лес. В тому числі на території області поширені льодовикові і водно-льодовикові відкладення, які під впливом геобіологічних процесів піддавались процесам ерозії [51].

Притясминські бори Черкаської області привертають увагу своїм походженням. Ще у 17 столітті на місці нинішнього Чигиринського лісгоспу можна було спостерігати сосново-дубові ліси. Це місце слугувало схованкою для гайдамак. За свідченням істориків, з метою знищення повстанців польські конфедерати випалювали прадавні ліси. Близько ста років по тому земські упорядники та науковці запроваджували новітні доробки 3 метою припинення сипучих пісків. Поруч із сосною звичайною висаджували до 9\% берези, бузини червоної, в’яза дрібнолистого, смородини золотистої. Однак, весняні суховії знищували саджанці, завіювали їх піском, пошкоджували бруньки. Звідси 3'явилось рішення: спочатку висадити шелюгу з метою закріплення та зупинення наступу пісків. По тому, через декілька років, між рядами шелюги насаджували саджанці сосни звичайної. Шелюгу спочатку зрубували на пні, яка потім сама гинула в тіні сосни. Застосовуючи сучасні підходи, використовуючи практику й досвід інших, працівники Чигиринського господарства всього за 10 років створили зелене море на місці колишньої рухомої пустелі [52].

Соснові ліси - світлохвойні ліси, що в своєму складі мають домінантний вид сосну звичайну в деревному ярусі. Такі деревостани найбільш поширені в лісовій і лісостеповій зонах помірного і субтропічних поясів, а також в гірському поясі. Представники цього виду активно виростають на супісках, пісках, вапняках, доломітах, торф'яних болотах. Соснові масиви виконують компенсаторну функцію щодо утримання грунтових вод та збільшенні врожаїв сільськогосподарських культур у зонах посушливого клімату, відіграють значну роль в зміцненні піщаних грунтів, ярів і гірських схилів, в захисті від снігових лавин та селевих потоків. 
Крони сосен вирізняються достатньою світлопроникністю, вони ажурні, пропускають багато сонця. Звідси, в сосновому лісі можна спостерігати слабке затінення, рослини нижніх ярусів досить добре освітлені. Тут, крім достатнього освітлення, і набагато сухіше. Під кронами сосен в різних грунтово-кліматичних умовах панують різні види рослини. На дуже сухих і бідних піщаних грунтах під деревами формується суцільний білий покрив із епіфітних кущових лишайників. На грунтах вологих, але збіднених і кислих, розвиваються густі зарості чорниці. Там, де грунт має помірну вологість і достатньо поживних речовин, розростається кислиця. На грунті в сосняках часто можна спостерігати суцільний моховий ярус, на тлі якого розвиваються характерні для всіх хвойних лісів мохи, трави і кущі.

Сосна звичайна - Pinus sylvestris L., родина соснові (Pinaceae). Латинська назва означає слово ріn - «скеля», що відображає найбільш улюблені місця сосни, яка часто вибирає скелясті обриви, схили гір. Слово sylvestris означає «лісовий». Походить це слово $з$ давнини, за припущеннями, бере початок від слова sop - сік, через соковитості, смолистості дерева. Сосна - одна з найбільш поширених деревних порід, їі деревостани утворюють чисті і змішані масиви на великих просторах. Pinus sylvestris - довговічний вид, що доживає до 300-400 років. Завдячуючи досить розгалуженій кореневій системі і численними якірними коренями, розташованими збоку від проекції стовбура, вона дуже вітростійка.

Сосна світлолюбна рослина. Характерною властивістю є мала густота крони, а також периферичне (на кінцях гілок і уздовж поверхні крони) розташування хвої, що покриває пагони останніх 2-3 років.

Стовбур сосни досить швидко очищається від сучків. Однак, соснові молодняки густі і тінисті, під ними створюється навіть мертвий покрив. Завдяки своїй малій вимогливості до тепла, ареал сосни поширюється далеко на північ, до кордонів тундри і в гори до альпійських галявин. Цю породу відносять до нестійкого, континентального клімату, як доказ цього іiі можна зустріти в географічних районах з широкою амплітудою температур, з суворою зимою і 
жарким літом. Лише молоді сходи і однорічні сіянці сосни страждають від сонячних опіків.

Сосна звичайна посухостійка порода. Про приналежність її до ксерофітів, свідчить досить розгалужена коренева система, що обумовлює її здатність брати вологу з великого обсягу товщі грунту. Можна сказати, що сосна подвійний ксерофіт: вона мало споживає вологи і вміє їі знаходити в умовах грунтової посухи за допомогою достатньо розгалуженої кореневої системи. Сосна маловимоглива до багатства грунту, оліготроф. Як доказ цієї властивості, вказують наступні ознаки: задовільно зростає на найбідніших піщаних грунтах, заселяє скелясті субстрати і піски, позбавлені нормального грунту.

Сосна - вид швидкоростучий. Фіксований приріст у висоту максимальний в віці 15-25 років, в південних районах - ще раніше. В сходів і саджанців низька чутливість до приморозків. Плодоношення настає рано: на просторі - у віці 1520 років, в насадженнях - в 50-60 років.

В сосни анемохорний тип запилення. Насіння іï крилате, висипається 3 шишок взимку. Воно може бути перенесене вітром на великі відстані, дерево 3 верхнього ярусу дає понад 100 шишок з 4500-5000 насінинами, а насадження на 1 га - понад мільйон насінин. Роль звичайної сосни в лісі подвійна. Цей вид серед перших розповсюджується на відкриті простори. Водночас, вона і основний лісоутворювач, здатний створювати свої довговічні насадження. Така властивість ऑї, як світлолюбність сприяє створенню змішаних насаджень, оскільки під наметом вікового соснового деревостану можуть проростати інші, більш тіньовитривалі види. Згодом вони можуть увійти до складу I ярусу, зайняти в ньому положення нарівні з сосною або навіть витіснити їі.

Сосна дає хорошу деревину, використовується для виробництва целюлози, 3 живиці добувають каніфоль і скипидар, з кори - дубильні речовини [53, 54].

Таким чином, виходячи 3 усього викладеного, науковий інтерес до соснових лісів залишається актуальним i, враховуючі всі вищезгадані властивості, можна активно їх використовувати в галузі розвитку сучасних технологій лісових культур та в подальшому розвитку лісівничої справи. 
Враховуючи, що тільки починає розвиватися синтаксономічний напрямок досліджень, недостатньо опрацьовані питання комплексного використання біологічного потенціалу соснових борів на Притясминських терасах 3 погляду сталого розвитку, відчувається брак табличного матеріалу для таксації деревостанів, що вимагає детальнішого їх вивчення та систематизації.

У зв’язку з цим важливе значення мають дослідження штучних лісів за участю сосни звичайної, без яких складно уявити регіональне природокористування і створення науково обгрунтованих підходів в системі наближеного до природи лісівництва.

Особливістю соснових борів на Притясминських пісках є їх рукотворне походження, оскільки під впливом антропогенного втручання вони зазнали радикальних змін. Ці бори відносяться до інтразональних природних лісових формацій Середнього Подніпров'я, де протягом багатьох років формувались деревостани сосни звичайної (Pinus sylvestris L.). Запровадження на практиці відповідних лісокультурних заходів, в напрямку штучного відтворення насаджень у соснових борах, дало позитивний результат на формування лісостанів. Однак, враховуючи відповідне значення лісів прирічкових екосистем, їх багатофункціональність вони й надалі потребують детального вивчення, оскільки бракує їх описів в лісівничій літературі.

Зрозуміло, що різноманітність рельєфу місцевості та окремі урочища відповідають певним лісорослинним умовам та мають подібність чи відмінності, що урізноманітнює якісні характеристики насаджень. Як відмічають ряд дослідників Бельгард А.Л. (1960), Герушинський 3.Ю. (1996), Гордієнко М.I. (2002), Краснов В.П. (2009) у повоєнні роки в нашій країні проведено значні роботи із залісення піщаних земель, ярів і балок, внаслідок чого на десятках тисяч гектарів з'явилися нові ліси та багаторічні насадження там, де їх не було впродовж сотень років $[55,56,57,54,58]$. До вищевказаних об'єктів відносяться і Притясминські піски.

Процес формування лісового біоценозу в культурах сосни звичайної створених на горбистих пісках, та їх типологічну оцінку досліджував 
В.В. Шлапак (2013), [59], зокрема, лісівничо-екологічні властивості Pinus sylvestris та особливості їі відтворення на Притясминських пісках.

В.П. Шлапак (2007) в своїх доробках висвітлював питання потенційних можливостей вирощування культур сосни в умовах пристепових борів на прикладі культур створених на початку минулого століття проф. 3.С. Голов'янком [60].

Особливості антропогенної трансформації трав'яних фітоценозів лісових екосистем Черкаського регіону, зокрема, Черкаського бору та Чигиринського соснового масиву вивчав Н.В. Мірошник (2016) [61].

Характеристику лісової рослинності за участю Daphne cneorum L. у межах Черкасько-Чигиринського геоботанічного району досліджувала Ю.Ю. Гайова (2013) [62].

Суспільно-економічне значення соснових насаджень на території України спонукало науковців різних напрямів до їх вивчення. Зокрема, свої наукові доробки їм присвятили 3.С. Голов'янко (1904, 1940), А.П. Тольський (1905, 1940), П.М. Погребняк $(1955,1971)$, П.П. Ізюмський (1987), I.I. Гордієнко (1969), Т.Т. Говорова (1965), А.Г. Гаєль (1952, 1965), В.М. Виноградов (1960, 1966), М.М. Дрюченко (1960), В.К. М'якушко (1978), .І. Редько (1980, 1990), М.I. Гордієнко (1979， 1992，2002，2007)， П.I. Мороз (2000，2006) та інші дослідники. Однак, їх праці висвітлювали проблеми формування соснових лісів рівнинної частини України, зокрема в Черкаському та Ізюмському борах і тільки деякою мірою вони дотичні Чигиринського бору, який входить до Притясминських борів, площею біля 23 тис. га, а враховуючи землі непридатні до сільськогосподарського використання, кар'єри, яри та балки, деяких заплав річки Тясмин площа під заліснення може бути збільшена до 100 тис. га [63].

Проте, вивчення особливостей формування соснових борів на Притясминських пісках на території Черкаської області потребують детальнішого вивчення. Фітоценотичний склад природної i культурної рослинності й визначають актуальність нашого дослідження. 
Вивчення та дослідження характеристик соснових лісів ДП «Чигиринське лісове господарство» грунтувалось на загальноприйнятих лісівничих та флористичних методиках. Для складання геоботанічних описів Притясминських фітоценозів та вивчення еколого-біологічних властивостей соснових борів проводилися маршрутні обстеження з описами та використанням довідкової літератури, насамперед, визначників [64, 65].

3 метою оцінювання ступеня відповідності сформованого фітоценозу умовам місцезростання ми використовували методику Й. Матушкевича та його визначник рослинних асоціацій, де за основу взято флористичну методику Браун-Бланке [66]. Згідно з цією методикою, Притясминські бори утворюють фітоценотичні групи хвойних бореальних лісів з досить рясно поширеним покривом за участі моху на території рівнинної та гірської частини України [66]. Їх синтаксономія є наступною:

VACCINIO-PICEETEA Br.-B1. 1939[67].

Cladonio-Vaccinietalia Kiell.-Lund 1967[67].

Dicrano-Pinion Libb. 1933[67].

Dicrano-Pinenion Seibert in Oberd. (ed.) 1992[67].

Cladonio-Pinetum Juraszek 1927[67].

Peucedano-Pinetum W. Mat. (1962) 1973[67].

Leucobryo-Pinetum Mat. (1962) 1973[67].

Molinio (caeruleae)-Pinetum W. Mat. et J. Mat. 1973[67].

Querco roboris-Pinetum (W. Mat. 1981) J. Mat. 1988[67].

Serratulo-Pinetum (W. Mat. 1981) J. Mat. 1988 [67].

Festuco ovinae-Pinetum Kobendza 1930[67].

Piceo-Vaccinienion uliginosi Seibert in Oberd. (ed.) 1992[67].

Vaccinio uliginosi-Betuletum pubescentis Libbert 1933[67].

Vaccinio uliginosi-Pinetum Kleist 1929[67].

Calamagrostio villosae-Pinetum Staszk. 1958 [67].

Vaccinio- Piceetalia Br.-B1. 1939[67].

Piceion abietis Pawt. et all. 1928[67]. 
Vaccinio-Abietenion Oberd. 1962[67].

Abietetum polonicum (Dziub. 1928) Br.-B1. Et Vlieg. 1939 [67].

Vaccinio-Piceenion Oberd. 1957[67].

Querco roboris-Piceetum (W. Mat. 1952) W. Mat. Et Poak. 1955 [67].

Згідно з дослідженнями Й. Матушкевича [66], сосновим лісам властивий набір характерних тільки для них видів, які утворюють комплекси характерних і діагностичних видів різного рангу (табл. 1).

Таблиця 1

Діагностичні види соснових лісів

\begin{tabular}{|c|c|}
\hline Українська назва виду & Латинська назва виду \\
\hline 1 & 2 \\
\hline Характерні види класу хвойних лісів - Vaccinio-Piceetea \\
\hline Дуб звичайний & Quercus robur \\
\hline Береза повисла & Betula pendula \\
\hline Груша звичайна & Pyrus communis \\
\hline Чорниця & Vaccinium myrtillus \\
\hline Брусниця & Vaccinium vitis-idea \\
\hline Верес & Calluna vulgaris \\
\hline Веснянка дволиста & Majanthenum bifolium \\
\hline Нечуйвітер волохатий & Hieracium pilosella \\
\hline Мітлиця тонка & Agrostis tenuis \\
\hline Чебрець повзучий & Thymus serpyllum \\
\hline Плевроцій Шребера & Pleurozium schreberi \\
\hline Дікран хвилястий & Dicranum polysetum \\
\hline Гілокомій блискучий & Hylocomium splendens \\
\hline Рунянка ялівцева & Polytrichum juniperinum \\
\hline Характерні види порядку соснових лісів Cladonio-Vaccinietalia \\
\hline Кладоніч оленяча & Cladonia rangiferina \\
\hline Дікран багатоніжковий & Dicranum polysetum \\
\hline Сосна звичайна & Pinus sylvestris \\
\hline Характерні види союзу соснових лісів Dicrano-Pinion \\
\hline Зимолюбка зонтична & Chimaphila umbellata \\
\hline
\end{tabular}


Продовження табл. 1

\begin{tabular}{|c|c|}
\hline 1 & 2 \\
\hline Конвалія звичайна & Convallaria majalis \\
\hline Щучка звивиста & Deschampsia flexuosa \\
\hline Діфазіаструм сплюснутий & Diphasiastrum complanatum \\
\hline Щитник австрійський & Dryopteris austriaca \\
\hline Гіпнум кипарисовидний & Hypnum cupressiforme \\
\hline Під ялинник звичайний & Hypopitys monotropa \\
\hline Ялівець звичайний & Juniperus communis \\
\hline Багно звичайне & Ledum palustre \\
\hline Левкобрій сизий & Leucobryum glaucum \\
\hline Плаун колючий & Lycopodium annotinum \\
\hline Ортилія однобока & Orthilia secunda \\
\hline Зозулин льон звичайний & Polytrichum commune \\
\hline Грушанка кругло листа & Pyrola chlorantha \\
\hline Золотушник звичайний & Solidago virgaurea \\
\hline
\end{tabular}

Для проведення досліджень, які включали флористичні описи, насамперед, необхідно було правильно підібрати та визначити мінімальні площі дослідних ділянок для здійснення опису, фіксації повного видового складу фітоценозу 3 урахуванням сезонних явищ. Також, необхідно було визначити застосування відповідних шкал для здійснення кількісних та якісних характеристик видів, діагностика таблиць. У соснових фітоценозах видовий склад ми констатували здійснюючи два описи, в різний вегетаційний період з інтервалом в один місяць - у момент появи найбільшої кількості видів. А саме - це середина травня та друга половина червня.

Як констатував Ф. Фукарек, мінімальна площа, на якій проявляються характерні для фітоценозу ценотичні взаємозв'язки, для лісового типу рослинності складає 500-2500 м² - ліси, деревний та кущовий яруси, 100-400 м² - трав'яні яруси, 1-4 м² - ярус мохів, 0,1-1 м² - угруповання лишайників [68]. Для вивчення необхідних параметрів соснових лісів дослідні ділянки фіксувались 
розміром 50х50 м, в межах яких закладалися дослідні площі розміром 2х2 м, для дослідження трав’яної рослинності.

Для опису ярусності фітоценозу використано систему позначок: деревний ярус - A, чагарниковий - B, трав'яний - C, мохово-лишайниковий - D. Виділяли також під’яруси: А1, C1.

У фітоценотичних описах для кожного виду наводили його кількісні (відсоток покриття, рясність, частота трапляння, постійність) та якісні характеристики (життєва форма, товариськість, феностан, життєвість). Кількісні характеристики видів у фітоценозі виражали 7-ступеневою комбінованою шкалою Ж. Браун-Бланке, яка водночас відображає рясність та відсоток вкриття виду на ділянці: 5 - кількість особин довільна, вкриття $>75 \%$ поверхні ділянки опису; 4 - кількість особин довільна, вкриття 50-75\%; 3 - кількість особин довільна, вкриття 25-50\%; 2 - кількість особин велика, вкриття 5-25\%; 1 кількість представників виду велика (від 5 до 50), площа покриття біля 5\%; + кількість особин мала (від 2 до 5), вкриття $<5 \%$; - одинична особина. Така шкала ступенями 5, 4, 3 і 2 краще характеризує процент вкриття виду, а ступенями 1, +, r - кількість особин. Вона дуже зручна для застосування у природі, на відміну від десятиступеневої, яку застосовували раніше [54,70,69].

Для визначення рясності користувались шкалою О. Друде: soc (sociales) (рясно) вид суцільно вкриває площу надземними органами; cop3 (copiosae)(розсіяно) надземні частини вкривають від 1/2 до 3/4 площі; cop2 - вегетативна частини фітоценозів вкривають від 1/4 до 1/2 площі; cop1 - (зрідка) вегетативна частини фітоценозів розміщена від 1/20 до 1/4 площі; sp (sparsae) - (рідко) вегетативні частини рослин вкривають менше 1/20 площі; sol (solitariae) (поодиноко) трапляються поодинокі рослини; un (unicum) - одна або дві особини на ділянці фітоценозу. Взята шкала ідентична шкалі рясності за Г.Висоцьким, у первинних описах ми використовували обидві із співставленням позначок: 5 суцільне вкриття даного виду; 4 - вид панує над іншими і займає $>50 \%$ площі; 3 - рясне поширення виду, вкриває 5 - 20\% площі; 2 - помірне поширення виду, 
вкриває 5 - 20\% площі; 1 - слабке поширення виду, вкриває $<5 \%$ площі; р розсіяні особини; $\mathrm{n}$ - поодинокі особини $[54,70,69]$.

Феностан покритонасінних рослин визначали за шкалою В. Альохіна [63,77,87], для спорових iї трохи коригували: - - вегетація до цвітіння; ^ бутонізація; ) - розцвітання; О - масове цвітіння; ( - відцвітання; + - рослина відцвіла, плоди не дозріли; \# - плоди та насінини опадають; - вегетація після плодоношення.

Життєвість, яка відображає рівень пристосування рослини до зовнішніх факторів і є мірою її зони комфорту, визначали за 4-ступеневою шкалою: 1 рослина проходить повний життєвий цикл; 2 - рослина проживає частину своєї онтогенетичної програми, але має досить потужну систему рослинних органів; 3 - рослина існує частину життєвого циклу, наявні мало пристосовані вегетативні органи; 4 - рослина гине після проростання [54, 70, 69].

Трапляння вираховували як відсоток або абсолютну кількість фітоценозів, які включають певний вид.

Постійність за А. Скамоні (частота трапляння виду в межах певного синтаксону), визначали як відсоток фітоценозів, у яких виступає вид [52]. Цей показник визначається за 5-ступеневою шкалою класів: I $-<10 \%$ фітоценозів містять вид; II - 10-30\% фітоценозів містять вид; III - 30-50\% фітоценозів містять вид; IV - 50-60\% фітоценозів містять вид; V - > 60\% фітоценозів містять вид.

Для виявлення взаємозв'язків та подібності між описами ми використовували коефіцієнт подібності Жаккара [70, 69]:

$$
K_{j}=\frac{c}{a+b-c},
$$

де $a$ - кількість видів в першому описі;

$b$ - кількість видів в другому описі;

$c$ - кількість спільних видів у двох описах.

Місцерозташування державної установи “Чигиринське лісове господарство", що знаходить в підпорядкуванні Черкаського обласного 
управління лісового та мисливського господарства, інша назва ДП “Чигиринський лісгосп” відповідає такому географічному положенню, а саме: північно-східній частині Черкаської області на межі Чигиринського i Черкаського адміністративних районів [71]. В структурі лісгоспу налічується шість лісництв. Адміністративно-господарська структура та загальна площа подана у табл. 2.

Таблиця 2

Територіально-адміністративна організація та територія ДП “Чигиринське лісове господарство”

\begin{tabular}{|c|c|c|}
\hline $\begin{array}{c}\text { Назва представництв, } \\
\text { розташування контор }\end{array}$ & $\begin{array}{c}\text { Адміністративно- } \\
\text { господарські райони }\end{array}$ & $\begin{array}{c}\text { Територія, } \\
\text { га }\end{array}$ \\
\hline 1 & 2 & 5628,6 \\
\hline $\begin{array}{c}\text { Чорнявське, } \\
\text { кв. } 36 \text { вид. 44, с. Чорнявка }\end{array}$ & Черкаський & 5327,1 \\
\hline Трушівське,кв. 19 вид. 4 & Чигиринський & 4043,6 \\
\hline $\begin{array}{c}\text { Чигиринське, } \\
\text { кв. 43 вид. } 1, \text { м. Чигирин }\end{array}$ & Чигиринський & 6192,9 \\
\hline $\begin{array}{c}\text { Матвіївське, } \\
\text { кв. } 59 \text { вид. 5, с. Матвіївка }\end{array}$ & Чигиринський & 5455,3 \\
\hline $\begin{array}{c}\text { Яничанське } \\
\text { кв. } 21 \text { вид.20, с. Іванівка }\end{array}$ & Чигиринський & 3313,3 \\
\hline Богданівське, с. Стецівка & Чигиринський & 29960,8 \\
\hline Всього по лісгоспу: & Черкаський & 5628,6 \\
\hline в т. ч. за адмінрайонами & Чигиринський & 24332,2 \\
\hline
\end{tabular}

ДП «Чигиринський лісгосп», як самостійна адміністративно господарська одиниця почав своє існування в 1958 р. відповідно до нормативно-правових актів Міністерства сільського господарства УРСР № 271 від 05.04.1958 р. і носив назву «Чигиринський степовий лісгосп» [71]. 
До складу «Чигиринського степового лісгоспу» входило п’ять лісництв: Чорнявське, Худоліївське (тепер Трушівське), Чигиринське, Матвіївське і Яничанське, а також урочища: Гущівське, Попово-Берестове, Чум'яне, Розсошинське, частина Чигиринського лісництва прийнятого від Олександрійського лісгоспу Кіровоградської області, а також Чорнявське лісництво Черкаського лісгоспу. Крім того, до складу лісгоспу увійшли захисні смуги вздовж Кременчуцького водосховища і Притясмянські піски [71].

На підставі постанови Ради Міністрів УРСР в 1959 році від 30.11.1959 р. № 134 «Чигиринський степовий лісгосп» був реорганізований в «Чигиринський лісгоспзаг» [75]. В період розбудови державної незалежності в 1991 році на реалізацію нормативних документів Міністерства лісового господарства України від 31.10.1991 р. № 133 на території «Чигиринського лісгоспзагу» був організований «Чигиринський державний лісгосп», до складу якого входили Чорнявське, Трушівське, Чигиринське, Матвіївське, Яничанське та Богданівське лісництво, яке було організоване в 2006 році переважно на основі земель лісового фонду колишніх сільськогосподарських підприємств, які були передані «Чигиринському лісгоспу» для охорони та ведення лісового господарства згідно з рішенням Черкаської обласної ради № 22-26 від 30.11.2001 року. Контора ДП «Чигиринське лісове господарство» розташована у м. Чигирин (рис. 2.1) [71].

Відповідно до районування за лісорослиними умовами місцерозташування лісгоспу належить до Правобережного лісостепу.

Якщо керуватись лісогосподарським розподіленням, то територія лісгоспу перебуває в зоні Дністровсько-Дніпровського лісостепового лісогосподарського округу.

Лісгосп перебуває під впливом природно-кліматичних факторів, які характерні для Південного лісостепу. Зокрема, характерні різкі перепади температур, мала кількість опадів, наявність у весняно-літній період досить великої кількості посушливих днів. 
Стисла інформація, що дає досить об'єктивну оцінку природногеографічних умов, що достатньо впливають на особливості ведення лісового господарства, приведена в таблиці 3.

Поміж кліматичних факторів, що здійснюють небажаний влив на життєві процеси деревних рослин, варто віднести значні коливання температурних показників ранньої весни й пізньої осені. Значні зміни температурного режиму, мала кількість опадів у вигляді дощу, досить велика кількість весняно-літніх спекотних днів. В загальному значенні, природно-кліматичні фактори згаданого лісорослинного району досить позитивно впливають на успішне зростання сосни, дуба, липи, ясеня, кленових, ряду завезених видів та екзотів.

Місцерозташування лісгоспу за типом рельєфу представляє собою територію з наявними глибокими низинами, ярами та байраками. На зіткненні 3 береговою долиною характеризується досить крутими береговими зниженнями. Весь лісовий резерв лісгоспу належить до рівнинних [71].

Таблиця 3

Природно-кліматичні характеристики ДП “Чигиринське лісове господарство” [71]

\begin{tabular}{|c|c|c|c|c|}
\hline $\begin{array}{l}\text { № } \\
\text { п/п }\end{array}$ & $\begin{array}{l}\text { Найменування } \\
\text { показників }\end{array}$ & $\begin{array}{c}\text { Одини } \\
\text { ці } \\
\text { вимірювання }\end{array}$ & $\begin{array}{r}\text { Значен } \\
\text { ня показника }\end{array}$ & Дата \\
\hline 1 & 2 & 3 & 4 & 5 \\
\hline 1. & $\begin{array}{c}\text { Температурні значення } \\
\text { повітря: } \\
\text { - середньорічна } \\
\text { - абсолютна максимальна } \\
\text { - абсолютна мінімальна }\end{array}$ & градус & $\begin{array}{r}7,5 \\
+37 \\
-35\end{array}$ & \\
\hline 2. & Кількість річних опадів & MM & 512 & \\
\hline 3. & Вегетаційний період & дні & 206 & \\
\hline 4. & Пізні весняні заморозки & & & 21.IV \\
\hline 5. & Перші осінні заморозки & & & $10 . \mathrm{X}$ \\
\hline 6. & Середня дата & & & 10-20.XII \\
\hline
\end{tabular}


Продовження табл. 3

\begin{tabular}{|c|c|c|c|c|}
\hline 1 & 2 & 3 & 4 & 5 \\
\hline 7. & Середня дата початку & & & 21.III \\
\hline 8. & $\begin{array}{c}\text { Снігові опади: } \\
\text { товщина } \\
\text { час появи } \\
\text { час сходження у лісі }\end{array}$ & $\mathrm{cm}$ & 20 & $\begin{array}{l}\text { 15. XI } \\
\text { 14. XII } \\
\text { 17. III }\end{array}$ \\
\hline 9. & Товщина промерзання & $\mathrm{cm}$ & 42 & \\
\hline 10. & $\begin{array}{l}\text { Напрямки найбільш } \\
\text { частих вітрів за } \\
\text { Порою року: } \\
\text { Зимовий період } \\
\text { Весняний період } \\
\text { Літній } \\
\text { Осінній }\end{array}$ & румб & $\begin{array}{r}3 \mathrm{x}, \\
\text { Пн3х } \\
\text { Пн3, } \\
\text { ПдСх, } \\
\text { Пд } \\
3 \mathrm{x}, \\
\text { Пн3х, ПдСх }\end{array}$ & \\
\hline 11. & $\begin{array}{l}\text { Середнє значення } \\
\text { швидкості вітрів за порою } \\
\begin{array}{lll}\text { року: } & & \\
& - & \text { зима } \\
& - & \text { весна } \\
& - & \text { літо } \\
& - & \text { осінь }\end{array}\end{array}$ & $\mathrm{M} / \mathrm{c}$ & $\begin{array}{l}4,3 \\
4,1 \\
3,5 \\
4,0\end{array}$ & \\
\hline 12. & $\begin{array}{l}\text { Відносна вологість } \\
\text { повітря (середньорічна) }\end{array}$ & $\%$ & 66 & \\
\hline
\end{tabular}

Проаналізувавши табл. 3, варто відмітити, що в загальному досить комфортний температурний режим, середня кількість надходження вологи, а також рівнинна місцевість даного регіону цілком сприятлива для зростання сосни звичайної (Pynus sylvestrys L.), дуба звичайного (Quercus robur L.), ясеня звичайного (Fraxinus excelsior L.), граба звичайного (Carpinus betulus L.), а також клена гостролистого (Acer platanoides L.) та інших цінних порід. Із факторів, що 
здійснюють деструктивний вплив на морфологічні, фізіологічні та інші життєві процеси лісових біоценозів, варто відзначити різкі зміни температурних режимів у весняно-осінній період.

В центральній частині лісогосподарської території простяглася Притясминська горбиста тераса з еоловими формами рельєфу. Вона має форму гряди, що простяглася вздовж берегової лінії р. Тясмин довжиною біля 50 км, завширшки 1,5-2,5 км від м. Черкаси до м. Чигирин, площею 12,7 тис. га. 3 цієї кількості площі під культури відведено 10,9 тис. га., які свого часу були створені на місці незадернілих пісків.

Переважають ясно-сірі і сірі середньо- та сильнозмиті грунти на схилах балок і підвищених пасом, горбів та останцевих ділянок лесового плато. У хвилястих межиріччях і на пологих схилах поширені сірі й темно-сірі опідзолені слабозмиті грунти, на ділянках плато - чорноземи типові та опідзолені. Грунтоутворюючі породи представлені лесами і лесовидними породами, на окремих ділянках - давніми та сучасними алювіальними відкладами.

На усій території підприємства можна виділити сім основних типів та видів грунтів:

- сірі лісові грунти - 38,7\% [71],

- чорноземи - 6,4\% [71],

- чорноземовидні - $1,4 \%$ [71],

- дернові - 49,6\% [71],

- лучні-0,1\%[71],

- лучно-болотні-0,1\% [71],

- болотні-0,6\% [71].

Деструктивні зміни грунтового середовища на території лісгосппідприємства мають низький відсоток впливу [71].

На грунтовій карті області (рис. 2.2) виділено 12 основних типів грунтів: темно-сірі опідзолені грунти, чорноземи опідзолені, сірі опідзолені грунти, чорноземи глибокі середньогумусні, лучні та чорноземно-лучні грунти, дерново- 
середньо- і слабопідзолисті супіщані і суглинкові грунти, дерново піщані та глинисто-піщані грунти, торфовища низинні та торфово-болотні грунти.

Таким чином, лісові фітоценози здійснюють достатній середовище формуючий вплив. Вирішальне значення при цьому мають еколого-біологічні властивості лісоутворюючих видів. Так, тіньовитривалі види дерев (ялини та ялиці), що утворюють в сприятливих умовах різновікові густі деревостани 3 зімкнутим пологом, сильніше впливають на середовище, ніж світлолюбні (сосна звичайна, модрина сибірська) одновікові рідкостійні деревостани з розріджені пологом. Територія лісгоспу розташована поблизу ріки Дніпро. За рівнем вологості значна частка грунтів належить до свіжих. Відсоток лісових земель 3 надмірним зволоженням складає 2,3 \% площі, вкритих лісовою рослинністю територій (табл.4).

Таблиця 4.

Особливості водотоку на території підприємства [71]

\begin{tabular}{|c|c|c|c|c|}
\hline \multirow{2}{*}{$\begin{array}{l}\text { Назва рік та } \\
\text { водоймищ }\end{array}$} & \multirow{2}{*}{ Куди впадає ріка } & \multirow{2}{*}{$\begin{array}{c}\text { Загальна } \\
\text { довжина, км; } \\
\text { площа } \\
\text { водоймищ, га }\end{array}$} & \multicolumn{2}{|c|}{$\begin{array}{c}\text { Параметри лісових посадок } \\
\text { поблизу берегових ліній річок, } \\
\text { біля озер та водоймищ м }\end{array}$} \\
\hline & & & $\begin{array}{c}\text { згідно } \\
\text { нормативів }\end{array}$ & фактична \\
\hline $\begin{array}{l}\text { Кременчуць } \\
\text { ке водосховище }\end{array}$ & p. Дніпро & 123 & 3000 & 3000 \\
\hline p. Тясмин & p. Дніпро & 62 & 300 & 300 \\
\hline р. Ірклій & р. Тясмин & 24 & 150 & 150 \\
\hline p. Чутка & p. Тясмин & 18 & 150 & 150 \\
\hline
\end{tabular}

До лісгоспу дотична низинна місцевість біля річки р. Тясмин. На ній свого часу були здійснені осушувально-меліоративні роботи й збудована система каналів, що створює необхідний вплив на життєві процеси лісових насаджень Чорнявського, Трушівського, Чигиринського лісництв. Рівень грунтових вод 
змінюється протягом року в низових долинах рік 0,5-3,0 м., та в борових ярусах рельєфу 5-7 м., на підвищеннях 18-26 м.

За результатами досліджень, здійснених у соснових деревостанах ДП «Чигиринське лісове господарство», можна зробити наступні висновки: Цінність лісів із участю чи домінуванням сосни звичайної (Pinus sylvestris L.) на території ДП «Чигиринське лісове господарство» полягає в тому, що вони єдині здатні формувати досить продуктивні насадження на Притясминських борових пісках, закріплюючи рухомі піщані дюни та утримуючи вологу у поверхневих шарах грунту. Особливістю Притясминських борів є їх штучне походження, що $\epsilon$ цікавим та цінним матеріалом для наукових досліджень, подальших пошуків зміцнення їх біоценотичних структур та збільшення їх біорізноманіття. Деревостани сосни звичайної, досліджені нами, є переважно чистими за складом, або 3 невеликою участю інших видів, одно- чи двоярусні, середньо- та високоповнотні, найбільші площі соснових борів у ДП «Чигиринське ЛГ»є у Чигиринському лісництві, де їх частка за площею складає 44\%. Для підвищення біологічної стійкості лісових культур слід вирощувати березу повислу та дуб звичайний. Також, враховуючи, наукові доробки фахівців лісівничої галузі, доречно проводити штучну мікоризацію угідь. Доцільним є також збереження лишайникового вкриття на пісках, оскільки окрім зниження температури грунту, лишайники мають здатність до первинної його мікоризації. 